\title{
EFFECTS OF THE USE OF SOYBEAN OIL AND ANIMAL FAT IN THE DIET OF LAYING HENS ON PRODUCTION PERFORMANCE AND EGG QUALITY
}

\author{
Efeito do uso de oleo de soja e gordura animal na dieta de poedeiras \\ sobre desempenho produtivo e qualidade do ovo
}

\author{
Daniela Duarte de Oliveira ${ }^{1}$, Nelson Carneiro Baião ${ }^{2}$, Silvana de Vasconcelos Cançado ${ }^{3}$, \\ Benedito Lemos de Oliveira ${ }^{4}$, Ângela Maria Quintão Lana², Tadeu Chaves de Figueiredo ${ }^{5}$
}

\begin{abstract}
The effects of different dietary lipids on the fatty acid profiles of eggs produced by 20 and 54 wk old Dekalb laying hens were investigated. Laying hens were subjected to three defined treatments according to the source of lipid added to their diets: soybean oil, beef tallow, and a control diet (without the addition of oil). The experimental design was in a $3 \times 2$ factorial arrangement (three treatments and two different ages). The fatty acid composition of the yolks in the eggs produced by the laying hens was analyzed. The eggs produced by laying hens on the soybean oil diet had a large amount of polyunsaturated fatty acids (PUFA) omega-6 (n-6) and omega-3 (n-3) in their yolks $(23.55,2.30 \%$ respectively), whereas egg yolks from hens who were given beef tallow had higher percentages of monounsaturated fatty acids $(47.53 \%)$ compared to soybean oil (47.53\%) and the control diet $(38.72 \%)$. The percentages of trans fats present in the egg yolks in all treatments were considered very low $(0.91 ; 0,11 ; 0.05 \%)$. Young layers are more efficient at depositing n -3 fatty acids $(1.40 \%)$, specially C22:6 (0.76\%) with the best ratio n6:n-3 (13.97) compared to old layers $(1.35 ; 0.72 ; 14.81 \%$ respectively). Based on these results, it was concluded that the amount of fatty acids present in the egg yolks can be modified by the sources of lipids included in the diet and that independent of the sources of lipid in the diet and the age of the chicken, egg yolks have insignificant amounts of trans fatty acids.
\end{abstract}

Index terms: Egg yolks, laying hens, beef tallow, soybean oil, fatty acids.

\section{RESUMO}

Foram avaliados os efeitos de diferentes dietas lipídicas na composição de ácidos graxos (AG) de ovos produzidos por poedeiras Dekalb de 20 e 54 semanas de idade. As poedeiras foram submetidas a três tratamentos definidos de acordo com a fonte lipídica adicionada nas rações: óleo de soja, sebo bovino e ração controle (sem adição de óleo). O delineamento experimental foi inteiramente casualizado em arranjo fatorial 3x2 (três tratamentos e duas idades das galinhas). Foram analisadas as composições em ácidos graxos das gemas dos ovos produzidos pelas poedeiras. O perfil de ácidos graxos das gemas dos ovos, produzidos pelas aves alimentadas com rações contendo óleo de soja, apresentaram na sua composição grande quantidade de ácidos graxos poliinsaturados (PUFA) ômega 6 (n-6) and Omega 3 (n-3) (23,55; 2,30\% respectivamente), enquanto as gemas dos ovos de poedeiras que receberam sebo bovino apresentaram maiores porcentagens de AG monoinsaturados $(47,53 \%)$ na sua composição, comparados com dieta contendo óleo de soja $(47,53 \%)$ e dieta controle $(38,72 \%)$. As porcentagens de gordura trans presente nas gemas dos ovos de todos os tratamentos foram consideradas muito baixas $(0,91 ; 0,11 ; 0,05 \%)$. Poedeiras novas são mais eficientes em depositar AG n-3 $(1,40 \%)$, especialmente C22:6 $(0,76 \%)$ na gema do ovo, com melhor razão n6:n:3 $(13,97)$ comparado com poedeiras velhas $(1,35$; 0,$72 ; 14,81 \%$ respectivamente). Com base nesses resultados, foi concluído que a quantidade de ácidos graxos presentes na gema dos ovos podem ser modificadas de acordo com as fontes de lipídios oferecidas nas dietas e que, independente da adição de diferentes fontes lipídicas na ração e da idade das galinhas, as gemas dos ovos possuem quantidades insignificantes de gorduras trans.

Termos para indexação: Gema de ovos, poedeiras, sebo bovino, óleo de soja, ácidos graxos.

(Received in august 26, 2010 and approved in august 22, 2011)

\section{INTRODUCTION}

Oils and fats are concentrated sources of energy, essential to the composition of diets of high nutritional density and for maintenance of the calorie/protein equilibrium. When lipids are added to the diet of laying hens, they increase the energy density of the diet, improving palatability, reducing the caloric increase of the diet due to proteins and carbohydrates, increasing the metabolic energy efficiency and improving feed conversion, in addition to modifying the fatty acid (FA) profile of the egg yolk (BRUGALLI et al., 1998).

Beef tallow commonly used in the poultry industry is a byproduct of cattle slaughter, and is used as an energy source in chicken diets. Its FA composition consists of

${ }^{1}$ Aviário Santo Antônio/ASA - endereço completo - Nepomuceno, MG - daniela.ddo@uol.com.br

2Universidade Federal de Minas Gerais/UFMG - Departamento de Zootecnia - Belo Horizonte, MG

${ }^{3}$ Universidade Federal de Minas Gerais/UFMG - Departamento de Tecnologia e Inspeção - Belo Horizonte, MG

${ }^{4}$ Aviário Santo Antônio/ASA - Nepomuceno, MG

5Universidade Federal de Minas Gerais/UFMG - Belo Horizonte, MG 
about $45 \%$ oleic acid and only 1 to $3 \%$ linoleic acid. Soybean oil is another energy source often added to chicken diets; obtained by the processing of raw soybeans, it is composed mainly of oleic (C18:1), linoleic (C18:2), linolenic (C18:3) and palmitic (C16:0) fatty acids. Many unsaturated fatty acids can be formed from saturated fatty acids (SAT) by the additional reactions of elongation and or desaturation. Saturated (SAT) and monounsaturated fatty acids (MUFA) can be synthesized by animals; however, animals cannot synthesize linoleic acid (C18:2) and linolenic acid (C18:3) (LESKANICH; NOBLE, 1997; LEHNINGER et al., 2002). Elongation and desaturation of the $\mathrm{C} 18: 2$ and $\mathrm{C} 18: 3$ results in a series of others polyunsaturated fatty acids (PUFA). The PUFAs omega 6 (n-6), such as arachidonic acid (C20:4), are synthesized from linoleic acid and PUFAs omega 3 (n-3), such as eicosapentaenoic acid (C20:5, EPA), docosapentaenoic acid (C22:5, DPA), and docosahexaenoic acid (C22:6, DHA), which are synthesized from linolenic acid. The FA belonging to the n-6 series are important precursors of eicosanoids of the paracrine system, such as prostaglandins, leukotrienes, prostacyclins, tromboxanes, and hydroxyacids, whereas the $n-3$ series fatty acids participate in functions of the nervous and visual system tissues, are responsible for regulatory activities of cardiovascular homeostasis, and also play important regulatory functions in the immune system (LEVINSON et al., 1990; LESKANICH; NOBLE, 1997; NEURINGER et al., 1998).

The relationship between n- 6 and n- 3 fatty acids is important to human health because there is competition between the enzymes involved in the elongation and desaturation, for both linoleic acid and linolenic acid, and one cannot be converted into the other. The Lyon Heart Institute (France) recommends a $4: 1$ n-6:n-3 ratio (BRANDÃO et al., 2005; SIMOPOULOS, 2006). The nutritional quality of the egg and the amount of FA present in the yolk can be modified by lipids sources in the diets, for example, by adding vegetable oils. However, it is important to point out that in addition to the diet, the breed and age of the laying hen can also affect the yolk lipid composition (WHITEHEAD et al., 1991; SHAFEY et al., 1992; SCHEIDELER et al., 1998; MELUZZI et al., 2000; PARDÍO et al., 2005).

Based on this background, the objectives of this study were to evaluate the effects of the addition of soybean oil and beef tallow to the diet of 20 and 54 week-old laying hens on the profile of fatty acids in egg yolks.

\section{MATERIAL AND METHODS}

A total of 864 Dekalb white laying hens were utilized, of which half (432) were 20 weeks old (young layers) and half were 54 weeks old (old layers). The young and old layers were placed in two separate sheds in cages measuring $50 \times 45 \mathrm{~cm}$ with six chickens per cage $\left(375 \mathrm{~cm}^{2}\right.$ per hen). The duration of the experiment was eight weeks. The procedures used during the production period were the same for both sheds.

The treatments used were defined according to the lipid source added to the diets: treatment $\mathrm{A}$ - diet with $3.4 \%$ soybean oil, treatment $B$ - diet with $4.0 \%$ beef tallow, and treatment $\mathrm{C}$ - control diet (no addition of oil). The diets were formulated (Table 1 and 2) according to Rostagno et al. (2005). The energy level $(8.800 \mathrm{Kcal} / \mathrm{kg})$ was the same for the three treatments, according to Leeson and Summers (2001) and Leeson and Summers (2005).

The eggs used for analyses of FA composition were collected 30 days after the beginning of offering the experimental diets to the hens. Egg samples were composed of a pool of six egg yolks, with each one considered a repetition; total of three repetitions per treatment were performed. The analyses of FA compositions of the egg yolks were made by gas chromatography (GC) at the Oil and Fats Laboratory, University of Campinas (UNICAMP, Brazil) according to the standard methodology used by the laboratory based on Abril and Barclay (1999). The FA present in the samples of egg yolks were separated by GC (CGC AGILENT 6850 SERIES GC SYSTEM) using a 60-m long, 0.25-mm inner diameter, and $0.25-\mu \mathrm{m}$ film methylpolysiloxane capillary column (DB-23 AGILENT, 50\% cyanopropyl). The running time of each sample was approximately $60 \mathrm{~min}$. The carrier gases used were nitrogen (trail gas), hydrogen, helium, and synthetic air. The operating conditions of the chromatograph were: column flux, $1.00 \mathrm{~mL} / \mathrm{min}$; linear velocity, $24 \mathrm{~cm} / \mathrm{sec}$; detector temperature, $280^{\circ} \mathrm{C}$; injector temperature, $250^{\circ} \mathrm{C}$; oven temperature, $110^{\circ} \mathrm{C}$ for $5 \mathrm{~min}$, $110-215^{\circ} \mathrm{C}\left(5^{\circ} \mathrm{C} / \mathrm{min}\right), 215^{\circ} \mathrm{C}$ for $24 \mathrm{~min}$; volume of trail gas injected, $1.0 \mu \mathrm{L}$. Between samples the chromatograph was cleaned using isopropanol and petroleum ether. The experimental design for the evaluations of FA compositions in egg yolks was in a $3 \times 2$ factorial scheme; there were three treatments (diet containing soybean oil, beef tallow, and the control diet) and two ages of chickens (20 and 54 wk old layers). The comparisons of means were made by the Student-Newmann-Kewls (SNK) method (SAMPAIO, 2002). 
Table 1 - Composition of the experimental chicken diets.

\begin{tabular}{lccc}
\hline \multirow{2}{*}{ Ingredients (\%) } & \multicolumn{3}{c}{ Lipid Source } \\
\cline { 2 - 4 } & Soybean Oil & Beef tallow & Control \\
\hline Corn & 52.40 & 52.40 & 66.20 \\
Soybean Bran & 18.00 & 18.00 & 19.20 \\
Wheat Bran & 11.00 & 11.00 & 0.00 \\
Lime & 7.56 & 7.56 & 7.56 \\
Meat and bone meal 45\% & 6.40 & 6.40 & 6.40 \\
Inert (rice straw) & 0.60 & 0.60 & 0.00 \\
Salt & 0.26 & 0.26 & 0.26 \\
DL-Methionine & 0.15 & 0.15 & 0.15 \\
Mineral premix * & 0.10 & 0.10 & 0.10 \\
Vitamin premix * & 0.10 & 0.10 & 0.10 \\
Choline chloride 60\% & 0.03 & 0.03 & 0.03 \\
Soybean oil & 3.40 & 0.00 & 0.00 \\
Beef tallow & 0.00 & 4.00 & 0.00 \\
\hline
\end{tabular}

*Comercial Premix: vitamin A - 5,000,000 UI, vitamin D3 - 1,250,000 UI, vitamin E - 7,500 UI, vitamin K3 - 1,000 mg, vitamin B1 $1,000 \mathrm{mg}$, vitamin B2 - 2,000 mg, vitamin B6 - 2,000 mg, vitamin B12 - 7,500 $\mu \mathrm{g}$, niacin - 15,000 mg, panthotenic acid - $8000 \mathrm{mg}$, biotin $-30 \mathrm{mg}$, folic acid $-250 \mathrm{mg}$, choline $-150,000 \mathrm{mg}$, selenium $-90 \mathrm{mg}$, iodine $-350 \mathrm{mg}$, iron $-20.000 \mathrm{mg}$, copper $-5,000 \mathrm{mg}$, manganese $-39,000 \mathrm{mg}$, zinc $-27,500 \mathrm{mg}$, BHT $-500 \mathrm{mg}$.

Table 2 - Calculated nutritional levels of the experimental diets.

\begin{tabular}{lccc}
\hline \multirow{2}{*}{ Nutrients } & \multicolumn{2}{c}{ Diets } \\
\cline { 2 - 4 } & Soybean oil & Beef tallow & Control \\
\hline Calcium (\%) & 3.82 & 3.82 & 3.82 \\
Metabolizable energy (Kcal/kg) & 2810 & 2808 & 2805 \\
Etherous extract (\%) & 6.7 & 6.7 & 3.5 \\
Available phosphorus (\%) & 0.8 & 0.48 & 0.46 \\
Digestible lysine (\%) & 0.74 & 0.74 & 0.75 \\
Dry matter (\%) & 89.15 & 89.15 & 88.56 \\
Methionine + cystine (\%) & 0.63 & 0.63 & 0.64 \\
Digestible methionine (\%) & 0.39 & 0.39 & 0.39 \\
Crude protein $(\%)$ & 17.08 & 17.08 & 17.03 \\
Sodium $(\%)$ & 0.18 & 0.18 & 0.19 \\
\hline
\end{tabular}

Source: Rostagno et al. (2005).

\section{RESULTS ANDDISCUSSION}

Each saturated fatty acid (SAT) analyzed had a different profile in egg yolks laid by chickens fed different diets (Table 3). These differences may be due to the SAT content found in the diets and also to the metabolism of the unsaturated fatty acids. Mazalli et al. (2004) also found similar values and noted that there is variation in the characteristics of yolk profiles when different sources of lipids were used in the diet of laying hens.

Among all the SAT, C16:0 and C18:0 had the highest percentage in the egg yolk composition, while very low levels of trans fatty acids (trans FA) were detected in the egg yolks of soybean $(0.91 \%)$, beef tallow $(0.11 \%)$ and control diet $(0.05 \%)$, independent of the diets given to the laying hens and and independent of the laying hen age $(0.85 \%)$. The levels of trans FA found in the egg are less 
than $2 \%$, which is not considered relevant in food composition according to ANVISA - Agência Nacional de Vigilância Sanitária (ANVISA, 2005).

No differences $(p>0,05)$ were seen in the majority of FA in the yolks laid by young and old laying hens, except for the FAs C14:0, C16:0, and C18:0, which were present in greater amounts in egg yolks from old laying hens $(0.40 ; 23.40 ; 8.55 \%$ respectively). Thus, the diet fed to the hens had a significant effect $(p<0,05)$ on the distribution pattern of the monounsaturated fatty acids and polyunsaturated fatty acids (PUFA) in the egg yolks (Table 4).

The egg yolks of laying hens that received the diet containing beef tallow showed a higher proportion of the FAs C18:1 (43.57\%), C20:1 (0.26\%), and 18:4 (0.28\%) than the yolks of laying hens that received the diet containing soybean oil $(35.94 ; 0.20 ; 0.09 \%$ respectively) or the control $\operatorname{diet}(41.86 ; 0.24 ; 0.10 \%$ respectively) $(\mathrm{p}<0,05)$. However, for the precursor of n-6 and n-3 chains, the highest proportions were found in the egg yolks of laying hens that received the diet containing soybean oil. The percentage of $\mathrm{C} 18: 2(21.63 ; 12.24 ; 13.29 \%)$ was significantly higher $(\mathrm{p}<0,05)$ than the percentage of $\mathrm{C} 18: 3(1.08 ; 0.29$; $0.25 \%$ ), a precursor of the $n-3$ chain, independent of the age. Ideally, these FAs should be balanced, since they are important for human health as the precursors of the longer n-3 fatty acids (C20:5, C22:5, C22:6) and n-6 chains (C20:4). In addition, these FAs are not synthesized by mammals and can only be obtained by food consumption (OLIVEIRA et al., 2009). Shafey et al. (1992) observed that the addition of vegetable oils to the diet of laying hens led to an increase in the percentage of C18:2 in the yolk compared to control diet. There was no significant difference $(\mathrm{p}>0.05)$ between treatments for $\mathrm{C} 20: 5(0.39 ; 0.24 ; 0.35 \%)$, that is usually found in very small amounts in eggs. However, when sources rich in n-3 FA, such as fish and linseed oils, are added to

Table 3 - Percent mean composition of the saturated fatty acids and trans fatty acids of the egg yolk in accordance with the lipid source (soybean oil and beef tallow) used in the diet and age of the laying hens (20 and 54 weeks age).

\begin{tabular}{lccccccccc}
\hline \multirow{2}{*}{ Lipid source /Age } & \multicolumn{7}{c}{ Fatty Acids (\%) } \\
\cline { 2 - 10 } & C14:0 & C15:0 & C16:0 & C17:0 & C18:0 & C20:0 & C18:1t & C18:2t & C18:3t \\
\hline Soybean oil & $0.34 \mathrm{c}$ & $0.31 \mathrm{~b}$ & $23.06 \mathrm{~b}$ & $0.35 \mathrm{~b}$ & $8.93 \mathrm{a}$ & $0.03 \mathrm{~b}$ & $0.20 \mathrm{~b}$ & $0.06 \mathrm{~b}$ & $0.07 \mathrm{a}$ \\
Beef tallow & $0.47 \mathrm{a}$ & $0.65 \mathrm{a}$ & $23.11 \mathrm{~b}$ & $0.55 \mathrm{a}$ & $8.52 \mathrm{~b}$ & $0.09 \mathrm{a}$ & $0.29 \mathrm{a}$ & $0.14 \mathrm{a}$ & $0.11 \mathrm{a}$ \\
Control & $0.40 \mathrm{~b}$ & $0.53 \mathrm{a}$ & $24.70 \mathrm{a}$ & $0.30 \mathrm{c}$ & $9.10 \mathrm{a}$ & $0.03 \mathrm{~b}$ & $0.23 \mathrm{~b}$ & $0.45 \mathrm{~b}$ & $0.05 \mathrm{a}$ \\
\hline Young layers & $0.42 \mathrm{a}$ & $0.53 \mathrm{a}$ & $23.85 \mathrm{a}$ & $0.40 \mathrm{a}$ & $9.15 \mathrm{a}$ & $0.55 \mathrm{a}$ & $0.24 \mathrm{a}$ & $0.07 \mathrm{a}$ & $0.08 \mathrm{a}$ \\
Old layers & $0.40 \mathrm{~b}$ & $0.46 \mathrm{a}$ & $23.40 \mathrm{~b}$ & $0.40 \mathrm{a}$ & $8.55 \mathrm{~b}$ & $0.48 \mathrm{a}$ & $0.25 \mathrm{a}$ & $0.09 \mathrm{a}$ & $0.08 \mathrm{a}$ \\
\hline
\end{tabular}

Averages followed by different letters in the column, per treatment or age, differ among themselves by the SNK test $(\mathrm{p}<0.05) ;{ }^{*} \mathrm{C} 12: 0=$ lauric acid; $\mathrm{C} 14: 0=$ miristic acid; $\mathrm{C} 15: 0=$ pentadecanoic acid; $\mathrm{C} 16: 0=$ palmitic acid; $\mathrm{C} 17: 0=$ margaric acid; $\mathrm{C} 18: 0=$ stearic acid; $\mathrm{C} 20: 0=$ arachidic acid; $\mathrm{C} 22: 0=$ docosanoic acid; $\mathrm{C} 24: 0=$ tetracosanoic acid; $* \mathrm{C} 18: 1 \mathrm{t}=$ trans oleic acid; $\mathrm{C} 18: 2 \mathrm{t}=$ trans linoleic acid; $\mathrm{C} 18: 3 \mathrm{t}=$ trans linolenic acid; young layers $=20$ weeks old; old layers $=54$ weeks old .

Table 4 - Percent composition of monounsaturated and polyunsaturated fatty acids in the egg yolks, in accordance with the lipid source (soybean oil and beef tallow) and age of the laying hens (20 and 54 weeks age).

\begin{tabular}{lcccccccccc}
\hline \multirow{2}{*}{ Lipid source /Age } & \multicolumn{10}{c}{ Fatty Acids (\%) } \\
\cline { 2 - 10 } & $\mathrm{C} 16: 1$ & $\mathrm{C} 18: 1$ & $\mathrm{C} 20: 1$ & $\mathrm{C} 18: 2$ & $\mathrm{C} 18: 3$ & $\mathrm{C} 18: 4$ & $\mathrm{C} 20: 4$ & $\mathrm{C} 20: 5$ & $\mathrm{C} 22: 5$ & $\mathrm{C} 22: 6$ \\
\hline Soybean oil & $2.20 \mathrm{~b}$ & $35.94 \mathrm{c}$ & $0.20 \mathrm{c}$ & $21.63 \mathrm{a}$ & $1.08 \mathrm{a}$ & $0.09 \mathrm{~b}$ & $1.92 \mathrm{~b}$ & $0.39 \mathrm{a}$ & $0.11 \mathrm{a}$ & $1.08 \mathrm{a}$ \\
Beef tallow & $3.00 \mathrm{a}$ & $43.57 \mathrm{a}$ & $0.26 \mathrm{a}$ & $12.24 \mathrm{c}$ & $0.29 \mathrm{~b}$ & $0.28 \mathrm{a}$ & $1.82 \mathrm{~b}$ & $0.24 \mathrm{a}$ & $0.07 \mathrm{~b}$ & $0.61 \mathrm{~b}$ \\
Control & $3.05 \mathrm{a}$ & $41.86 \mathrm{~b}$ & $0.24 \mathrm{~b}$ & $13.29 \mathrm{~b}$ & $0.25 \mathrm{c}$ & $0.10 \mathrm{~b}$ & $2.09 \mathrm{a}$ & $0.35 \mathrm{a}$ & $0.00 \mathrm{c}$ & $0.53 \mathrm{c}$ \\
\hline Young layers & $2.68 \mathrm{a}$ & $40.12 \mathrm{a}$ & $0.23 \mathrm{~b}$ & $15.50 \mathrm{~b}$ & $0.54 \mathrm{a}$ & $0.17 \mathrm{a}$ & $1.96 \mathrm{a}$ & $0.33 \mathrm{a}$ & $0.06 \mathrm{a}$ & $0.76 \mathrm{a}$ \\
Old layers & $2.82 \mathrm{a}$ & $40.79 \mathrm{a}$ & $0.25 \mathrm{a}$ & $15.94 \mathrm{a}$ & $0.54 \mathrm{a}$ & $0.14 \mathrm{a}$ & $1.93 \mathrm{a}$ & $0.31 \mathrm{a}$ & $0.06 \mathrm{a}$ & $0.72 \mathrm{~b}$ \\
\hline
\end{tabular}

Averages followed by different letters in the column, per treatment or age, differ among themselves by the SNK test ( $<<0.05) ; *$ C16:1 = palmitoleic acid; $\mathrm{C} 18: 1=$ oleic acid; $\mathrm{C} 20: 1=$ gadoleic acid; $\mathrm{C} 18: 2=$ linoleic acid; $\mathrm{C} 18: 3=$ linolenic acid; $\mathrm{C} 18: 4=$ stearidonic acid; C20:3 = eicosatrienoic acid; C20:4 = arachidonic acid; C20:5 = eicosapentanoic acid - EPA; C22:5 = docosapentanoic acid DPA; C22:6 = docosahexanoic acid $=$ DHA; young layers $=20$ weeks old; old layers $=54$ weeks old. 
the hen's diets, these values tend to increase in the yolk (BAUCELLS et al., 2000). There was an increase in the percentages of both DPA and DHA when soybean oil $(0,11$; 1,08 respectively) and beef tallow $(0.07 ; 0.61 \%$ respectively $)$ were added to the diet of the laying hens compared to the control diet $(0.00 ; 0.53 \%$ respectively). Also young layers can deposit more DHA to the egg yolk $(0.76 \%)$ than old layers $(0.72 \%)$. Since soybean oil already has a high percentage of $\mathrm{C} 18: 3(1.08 \%)$ compared to beef tallow $(0.29 \%)$ and control diet $(0.25 \%)$, hens fed soybean oil have more $\mathrm{n}-3(2.30 \%)$ and long chain PUFA $(26.32 \%)$ in their egg yolks than beef tallow $(1.00 ; 15.72 \%)$ and control diet $(0.82 ; 16.55 \%)$ independent of the age. The DHA levels found in the egg yolks ( $1.08 \%$ of soybean oil; $0.61 \%$ of beef tallow and $0.53 \%$ of control diet) were much higher than those of EPA $(0.39 ; 0.24 ; 0.35 \%$ respectively for soybean oil, beef tallow and control diet), as also seen by Marshall et al. (1994) and Baucells et al. (2000), however, it should be noted that EPA is an intermediary fatty acid in the formation of DHA from linolenic acid. Mazalli et al. (2004), evaluating the influence of canola, sunflower, linseed, and fish oils in the diets of laying hens on the FA composition of the yolk which are rich sources of $n-3$, did not detect EPA in any yolks, independent of treatments.

There is a concern regarding the EPA and DHA levels in the egg yolks of laying hens, because these FAs, in addition to having longer chains, are polyunsaturated and belong to the $n-3$ series. They should be increased by at least three times in an enriched egg compared to a normal egg, making these enriched eggs desirable for human health due to the important relationship between these FAs and their functions in the human body, principally for fetal and infant brain development and in the fight against circulatory problems due to their close relationship with cholesterol (HDL) (MARSHALL et al., 1994).
There was a significant statistical difference $(\mathrm{p}<0.05)$ in the percentage of the FAs C20:1, C18:2 and $\mathrm{C} 22: 6$ in the egg yolks from young $(0.23 ; 15.50 ; 0.76 \%$ respectively) and old layers $(0.25 ; 15.94 ; 0.72$ respectively), independent of the diet provided for them. It can be concluded that young laying hens are more efficient in the deposition of DHA $(0.76 \%)$ in the egg yolk compared to old layers $(0.72 \%)$, confirming the findings of Oliveira et al. (2009). It is believed that this difference between young and old layers is due to the hepatic efficiency in metabolizing the FAs from the diet and rearranging them in MUFA or PUFA. However, if we compare the percentages of these FAs with those shown in the egg yolks of hens whose diet was supplemented with fish oil, canola oil, or linseed oil (greater than 2\%), the values found in this study are very low thus contributing minimally to human health (LATOURet al., 1998; GAO; CHARTER, 2000; MARSHALL et al., 1994; MAZALLI et al., 2004).

Table 5 shows the total percent composition of SAT, MUFA, PUFA, trans, n-6, n-3, and the ratio between n-6 and $n-3$. The composition of the yolk varied in accordance to the source of lipid used in the diet. The yolk of the laying hens showed different patterns of the total SAT, MUFA, and PUFA. The yolks of the laying hens that received the control diet showed greater percentages of SAT. Egg yolks at treatment with beef tallow showed the highest percentages of total MUFA and trans fatty acids. Mazzali et al. (2004) observed that the quantity of SAT in the egg yolk compared to the quantity of total FA varies from 30 to $38 \%$, independent of the lipid source added to the diet (canola, sunflower, flaxseed or fish oil). Baucells et al. (2000), evaluating fish oils, linseed oil, sunflower oil, and beef tallow in the diet of laying hens also found constant quantities of SAT in yolks composition.

Table 5 - Total percent composition of saturated fatty acids (SAT), monounsaturated (MUFA), polyunsaturated (PUFA), trans, omega 6 (n-6), and omega 3 fatty acids (n-3), and the ratio between n-6:n-3 of egg yolks in accordance with the lipid source (soybean oil and beef tallow) and age of the laying hens (20 and 54 weeks age).

\begin{tabular}{lccccccc}
\hline \multirow{2}{*}{ Lipid source /Age } & \multicolumn{7}{c}{ Total Fatty Acids (\%) } \\
\cline { 2 - 8 } & SAT & MUFA & PUFA & trans & $\mathrm{n}-6^{1}$ & $\mathrm{n}-3^{2}$ & $\mathrm{n} 6: \mathrm{n} 3$ \\
\hline Soybean oil & $33.07 \mathrm{c}$ & $38.72 \mathrm{c}$ & $26.32 \mathrm{a}$ & $0.33 \mathrm{~b}$ & $23.55 \mathrm{a}$ & $2.30 \mathrm{a}$ & $10.25 \mathrm{a}$ \\
Beef tallow & $33.45 \mathrm{~b}$ & $47.53 \mathrm{a}$ & $15.72 \mathrm{c}$ & $0.55 \mathrm{a}$ & $14.06 \mathrm{c}$ & $1.00 \mathrm{~b}$ & $14.10 \mathrm{~b}$ \\
Control & $35.08 \mathrm{a}$ & $45.58 \mathrm{~b}$ & $16.55 \mathrm{~b}$ & $0.35 \mathrm{~b}$ & $15.38 \mathrm{~b}$ & $0.82 \mathrm{c}$ & $18.83 \mathrm{c}$ \\
\hline Young layers & $34.45 \mathrm{a}$ & $43.52 \mathrm{~b}$ & $19.35 \mathrm{a}$ & $0.39 \mathrm{a}$ & $17.47 \mathrm{~b}$ & $1.40 \mathrm{a}$ & $13.97 \mathrm{a}$ \\
Old layers & $33.28 \mathrm{~b}$ & $44.36 \mathrm{a}$ & $19.71 \mathrm{a}$ & $0.42 \mathrm{a}$ & $17.87 \mathrm{a}$ & $1.35 \mathrm{~b}$ & $14.81 \mathrm{~b}$ \\
\hline
\end{tabular}

Averages followed by different letters in the column, per treatment or age, differ among themselves by the SNK test $(\mathrm{p}<0.05) ;{ }^{1} \mathrm{n}-6=\mathrm{C} 18: 2$ and C20:4; ${ }^{2} \mathrm{n}-3=\mathrm{C} 18: 3, \mathrm{C} 20: 5, \mathrm{C} 22: 5 ; \mathrm{C} 22: 6 ;$ young layers $=20$ weeks old; old layers $=54$ weeks old. 
The total amount of PUFA did not show any significant difference $(p>0.05)$ between layers age however, there was significant difference $(p<0.05)$ between the treatments. Egg yolks of hens fed with soybean ratio had $26.32 \%$ of PUFA in their composition compared to $16.55 \%$ of control diet and $15.72 \%$ of beef tallow. However the amount of each individual FA cannot be analyzed. Each FA, n-6, n-3 or their ratio (n6:n-3), is nutritionally important to the composition of the egg (MARSHALL et al., 1994). The concentrations of $n-6(23.55 \%)$ and $n-3(2.30 \%)$ were greatest $(p<0.05)$ in egg yolks from laying hens fed with the diet containing soybean oil. Egg yolks of hens fed with beef tallow had more $n-3$ FA $(1.00 \%)$ than control diet $(0.82 \%)$ but less n-6 $(14.06 \%)$ compared to the control diet $(15.38 \%)$. The high level of n-3 present in the egg yolk from soybean oil diet led to a better n-6:n-3 ratio (10.25), compared to beef tallow diet (14.10) and control diet (18.83), however, these values are very high. This ratio should be as small as possible since values below $4: 1$ are considered excellent and have beneficial effects on human health (MARSHALL et al., 1994).

Only the total composition of PUFA and trans FA did not show differences between young $(19.35 ; 0.39 \%$ respectively) and old laying hens (19.71; $0.42 \%$ respectively). Young laying hens had a greater proportion of the saturated $(34.45 \%)$ and n-3 FA $(1.40 \%)$ and better values for the $n-6: n-3$ ratio $(13.97 \%)$ in relation to the old laying hens $(33.28,1.35 ; 14.81 \%)$, which showed higher percentages for MUFA (44.36\%) and n-6 (17.87\%) compared to egg yolk of young layers $(43.52 ; 17.47 \%$ respectively). These data is according to Marshall et al. (1994), who reported that young layers are more efficient in metabolizing FA, transforming them into long chain and unsaturated FA compared to old layers.

\section{CONCLUSION}

Fatty acid composition of yolks varies depending on the type of oil and fat used in the diet. The addition of soybean oil shows greater amounts of PUFA, n-3 and n-6 fatty acid compared to control and beef tallow diet. It also presented the best amounts of PUFA with long chain like C20:5, C22:5 and C22:6. Young layers and layers feed with soybean oil diet have at the yolk composition good ratio $n-6: n-3$. Independent of the addition of different lipid sources to the diet or the age of the laying hens, egg yolks have insignificant amounts of trans fats, and these should not be taken into consideration in the composition of the egg.

\section{ACKNOWLEDGMENTS}

The authors acknowledge FAPEMIG and CNPq for providing research funds and scholarship and Aviário Santo Antônio for providing the development of this experiment.

\section{REFERENCES}

ABRIL, R.; BARCLAY, B. Fatty acid analysis of poultry eggs as methyl esters. Método OT-GCPE, Revisão 3.1, 1999. 03/24/99.

ANVISA - Agência Nacional de Vigilância Sanitária. Resolução RDC n.270. 23 de set. 2005. Regulamento técnico para óleos vegetais, gorduras vegetais e cremes vegetais. Brasília, 2005.

BAUCELLS, M.D. et al. Incorporation of different polyunsaturated fatty acids into eggs. Poultry Science, Champaign, v.79, p.55-59, 2000.

BRANDÃO, P.A. et al. Ácidos graxos e colesterol na alimentação humana. Agropecuária Tecnica, Areia, v.26, p.5-14, 2005.

BRUGALLI, I.et al. Efeito dos níveis de óleo e proteína da dieta sobre a qualidade interna de ovos, em diferentes condições e tempo de armazenamento.

Revista Brasileira de Agrociência, Pelotas, v.4, p.187190, 1998.

GAO, Y.C.; CHARTER, E.A. Nutritionally important fatty acids in hen egg yolks from different sources. Poultry Science, Champaign, v.79, p.921-924, 2000.

LATOUR, M.A. et al. Broiler breeder age and dietary fat influence the yolk fatty acid profiles of fresh eggs and newly hatched chicks. Poultry Science, Champaign, v.77, p.47-53, 1998.

LEESON, S.; SUMMERS, JD. Commercial Poultry Nutrition. 3ed. Guelph: University Books, 2005. 398 p.

LEESON, S.; SUMMERS, J.D. Nutrition of the chicken. 4ed. Guelph: University Books, 2001. 415p.

LEHNINGER, A.L.; NELSON, D.L.; COX, M.M.

Princípios da bioquímica. 4.ed. Editora Sarvier, São Paulo, 2002.975p. 
LESKANISH, C.O.; NOBLE, R.C. Manipulation of the n-3 polyunsaturated fatty acid composition of avian eggs and meat. World's Poultry Science Journal, Cambridge, v.53, p.155-183, 1997.

LEVINSON, P.D. et al. Effects of n-3 fatty acids in essential hypertension. American Journal of Hypertens, New York, v.3, p.754-760, 1990.

MARSHALL, A.C. et al. N-3 fatty acid-enriched table eggs: A survey of consumer acceptability. Poultry Science, Champaign, v.73, p.1334-1340, 1994.

MAZALLI, M.R. et al. A comparison of the feeding value of different sources of fats for laying hens: 2 . Lipid, cholesterol, and vitamin E profiles of egg yolk. Journal Applied of Poultry Research, Champaign, v.13, p.280-290, 2004.

MELUZZI, A. et al. Effects of dietary vitamin $E$ on the quality of table eggs enriched with n-3 long chain fatty acids. Poultry Science, Champaign, v.79, p.539-545, 2000.

NEURINGER, M.; ANDERSON, G.J.; CONNOR, W.E. The essentiality of n-3 fatty acids for the development and function of the retina and brain. Annual Review of Nutrition, Palo Alto, v.8, p.517-541, 1998.

OLIVEIRA, D.D. et al. Fontes de lipídios na dieta de poedeiras: desempenho produtivo e qualidade dos ovos. Arquivo Brasileiro de Medicina Veterinaria e Zootecnia, Belo Horizonte, v.62, n.3, p.718-724, 2009 .
PARDÍO, V.T. et al. The effect of soybean soapstock on the quality parameters and fatty acid composition of the hen egg yolk. Poultry Science, Champaign, v.84, p.148157, 2005.

ROSTAGNO, H.S. et al. Tabelas brasileiras para suínos e aves: composição de alimentos e exigências nutricionais. 2.ed. Viçosa: UFV/DZO, 2005. 186p.

SAMPAIO, I.B.M. Estatística aplicada à experimentação animal. 2.ed. Belo Horizonte: FEPMVZ, 2002, 265p.

SCHEIDELER, S.E.; JARONI, D.; FRONING, G. Strain and age effects on egg composition from hens fed diets rich in n-3 fatty acids. Poultry Science, Champaign, v.77, p.192-196, 1998.

SHAFEY, T.M.; DINGLE, J.G; MCDONALD, M.W. Comparison between wheat, triticale, rye, soybean oil and strain of laying bird on the production, and cholesterol and fatty acid contents of eggs. British Poultry Science, London, v.33, p.339-346, 1992.

SIMOPOULOS, A.P. The omega-6/omega-3 ratio: the scientific evidence and the need to return the omega-3 fatty acids into eggs and other foods. In: J. Sim, and H. H. Sinwoo. The amazing egg: nature's perfect functional food for health promotion. Alberta: University of Alberta, 2006. p.195-218.

WHITEHEAD, C.C.; BOWMAN, A.S.; GRIFFIN, H.D. The effects of dietary fat and bird age on the weights of eggs and egg components in the laying hen. British Poultry Science, London, v.32, p.565-574, 1991. 